\title{
PERAN IBU SEBAGAI PENDIDIK DALAM KELUARGA
}

\author{
Mislaini \\ mislaini@gmail.com \\ Hoktaviandri \\ bokta.viandri81@.gmail.com \\ Indah Muliati \\ indahmuliati@.fis.unp.ac.id
}

\begin{abstract}
Abstrak
Ibu adalah sekolah yang sangat penting dalam membangun integritas anak-anak dalam rumah tangga. Oleh sebab itu ia harus mampu memberikan contoh baik bagi anak-anaknya. Anak belajar dengan cara meniru dari orang tuanya. Jika orang tua mencontobkan yang baik maka anak akan menjadi baik. Sebaliknya, jika ibu memberikan contoh yang buruk. maka anak.juga akan menjadi buruk karakternya. Dalam penanaman nilai-nilai yang baik kepada anak harus dimulai sejak usia anak. Sebab membentuk. karakter anak. lebih efektif ketika ia masib kecil. Namun jika sudab besar maka akan sulit dalam membentuk. kebiasaan yang baik. Ibu juga perlu memberikan dorongan belajar bagi anak-anak dengan mendidik mereka menggunakan metode cerita. Karena metode ini ikut serta dalam menanamkan nilai-nilai agama seperti menceritakan kisah-kisah nabi agar melabirkan pengaruh-pengarub baik pada jiwa anak-anak. Selanjutnya pengarub biburan dalam mendidik anak, juga sangat perlu diperhatikan oleh seorang ibu, agar anak-anak dapat memperoleh kegairahan roda kehidupan dalam belajar sesuai dengan usia anak dan tidak meleset dari nilai-nilai Islam. Semua metode pendidikan ini akan berdampak besar dan jelas dalam menumbubkembangkan kekuatan-kekuatan potensial yang ada pada anak, lebih-lebih potensi fisik, afektif dan kognitifnya.
\end{abstract}

Kata Kunci: Ibu, Pendidik, Keluarga.

\section{PENDAHULUAN}

Berbicara istilah Ibu, beliau adalah rumah bagi anak sebelum anak itu dilahirkan. Ibu adalah seorang pengajar yang memberi nasehat tentang petunjuk kehidupan ketika seorang anak membutuhkan petunjuk bimbingannya. Ibu adalah manusia ciptaan Allah yang memberikan sesuatu tanpa batas dan tidak mengharapkan imbalan apa-apa atas semua pemberiannya. Seorang anak yang senantiasa mendambakan ibu yang baik nan sholehah, taat menjalankan ibadah mabdah, rajin menjalankan syariat hukum sesuai dengan aturan agama Islam, memberikan kasih sayang yang tulus, mendidik dengan baik dan berbudi pekerti yang luhur. Itulah yang disebut dengan ibu ideal. dalam pandangan Islam. Wanita muslimah tidak pernah lupa bahwa tanggung jawab ibu dalam mengasuh anak dan membentuk kepribadian mereka lebih besar dari pada tanggung jawab ayah. ${ }^{1}$

Sebagaimana dijelaskan oleh Adil Fathi Abdullah dalam bukunya Menjadi Ibu Ideal yakni:

${ }^{1}$ Muhammad Ali al-Hasyimi, Muslimah Ideal, (Yogyakarta: Mitra Pustaka, 2004), h. 251-252 
"Tbu yang ideal adalah ibu yang berhasil dalam menjalankan peranannya secara maksimal sebagai seorang ibu. Ia harus dapat membaca pribadi anak-anaknya, persoalan dan problem yang dihadapi, bagaimana berinteraksi dengan mereka, bagaimana cara mendidik, bagaimana mengajarkan al-Qur'an, dan bagaimana mengajarkan masalah-masalah yang berkaitan dengan agama dan pendidikan, serta memiliki pengetahuan tentang sarana pendidikan modern dan cara penggunaannya."2

Ibu yang ideal menurut Islam adalah ibu yang mampu mendidik anak dengan nilai ke-Islaman, begitu juga, dengan pendidikan anak yang merupakan salah satu topik amat penting serta mendapat perhatian dalam Islam. Dengan pendidikan, anak akan mempunyai banyak ketrampilan dan kepribadian. Ketrampilan dan kepribadian merupakan syarat untuk menjadi makhluk yang berkualitas baik fisik maupun mental. Pribadi berkualitas dan berakhlak mulia tidak datang dengan sendirinya, tetapi ada semacam latihan-latihan kebiasaan yang baik akan berakibat baik dan menjadi bagian dari kepribadian keseharian, sebaliknya prilaku dan kebiasaan sehari-hari yang buruk juga akan berakibat buruk terhadap kepribadian.

Tidak ada yang meragukan betapa pentingnya peran ibu sebagai pendidik anak seperti kasih sayang dan perhatian dari seorang ibu. Karena perhatian dan kasih sayang tersebut akan menimbulkan perasaan diterima dalam diri anak-anak dan membangkitkan rasa percaya diri di masa-masa pertumbuhan mereka. Hal ini dipertegas oleh Lidia Yurita dalam bukunya Mukjizat Doa Ibu! Yang menyatakan bahwa "ibu muncul sebagai sosok yang siap siaga dan serba bisa. Kasih sayang, kelembutan dan perhatiannya menempatkan ibu menjadi sosok yang dibutuhkan seluruh anggota keluarga". ${ }^{3}$

Tak salah jika seorang ibu mempunyai peran yang sangat penting sebagai pendidik dalam keluarga, ini terbukti bagaimana seorang ibu mempersiapkan dan membekali dirinya baik lahir maupun batin dengan nilai-nilai kebaikan semenjak masih gadis kemudian bagaimana seorang ibu mengajarkan nilai- nilai tentang ketauhidan kepada anak-anaknya yang masih dalam kandungan walaupun hanya dengan belaian-belaian kasih sayang. Dengan demikian, wanita yang memahami ajaran Islam dan peran pendidikannya sendiri dalam kehidupannya tahu betul tanggung jawab pengasuhan anak-anak mereka.

Seiring dengan hal ini, Awaludin Habiburrahman dalam bukunya yang berjudul Terbaik Buat Anakku menyatakan bahwa:

"Tbu adalab ujung tombak dari tanggung jawab mendidik anak-anaknya sehingga dapat dikatakan bahwa baik buruk warna seorang anak sebagian besar dipengarubi oleh baik atau buruk warna kepribadian ibunya. Sehingga ibu yang sadar akan fungsinya yang menentukan masa depan anaknya akan berusaha sekuat tenaganya untuk menjadi ibu yang muslimah atau shalihah bagi anak-anaknya."

\footnotetext{
${ }^{2}$ Adil Fathi Abdullah, Menjadi Ibu Ideal, (Jakarta: Al-Kautsar, 2005), h.121.

${ }^{3}$ Ya'qub Chamidi, Menjadi Wanita Shalihah dan Mempesona, (Jakarta: Mitra Press Studio, 2011), h.190.

4Awaluddin Habiburrahman, Terbaik Buat Anakku, (Jakarta: Pustaka Group, 2009), h.34.
} 
Oleh karena itu, ibu merupakan orang pertama yang menjadi contoh dalam pendidikan bagi keluarga serta melindungi anak- anaknya dari kobaran api neraka. Hal ini dijelaskan oleh Allah SWT dalam surat At-Tahrim ayat 6 yang berbunyi:

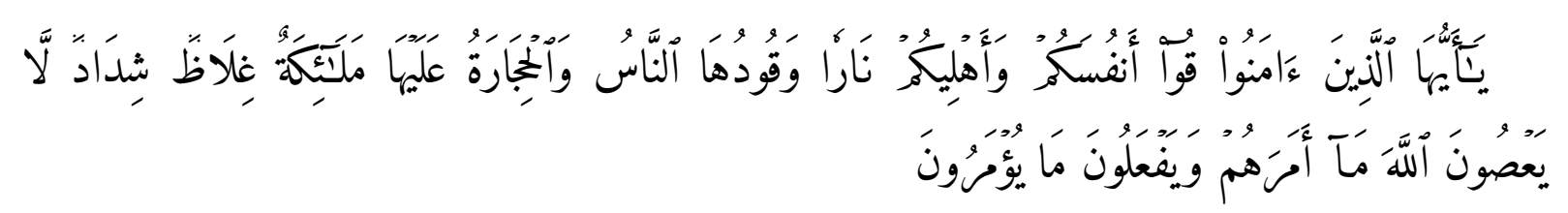

Hai orang-orang yang beriman, peliharalah dirimu dan keluargamu dari api neraka yang bahan bakarnya adalah manusia dan batu; penjaganya malaikat-malaikat yang kasar, keras, dan tidak mendurbakai Allah terhadap apa yang diperintabkan-Nya kepada mereka dan selalu mengerjakan apa yang diperintabkan.(Q.S. AtTabrim: 6). ${ }^{5}$

Perintah ini ditujukan kepada keluarga. Namun, dalam hal ini sosok ibu lah yang menjadi prioritas utama dalam mendidik anak di dalam keluarga, karena anak yang diharapkan di dalam keluarga yaitu anak yang shaleh. Dengan demikian realitas ini memberi kesan bahwa pendidikan pertama bagi anak adalah pendidikan yang diterimanya ketika di dalam keluarga. Pendidikan keluarga sangat penting, karena mempunyai pengaruh besar bagi anak dalam bergaul dan bermasyarakat. Ibu yang muslimah atau shalehah lah akan berusaha memberikan pengaruh keimanan dan ketakwaan yang kuat bagi jiwa anak-anaknya sehingga anak-anaknya tumbuh menjadi muslim yang taat dan terhindar dari api neraka.

Seorang penyair ternama Hafiæ Ibrahim mengungkapkan sebagai berikut:

Ibu adalah madrasah (Sekolab), bila engkau menyiapkan berarti engkau menyiapkan bangsa yang baik pokok pangkalnya. ${ }^{6}$

Dapat dipahami bahwa ibu adalah madrasah pertama yang akan memberikan qudwah (keteladanan) bagi sikap, perilaku dan kepribadian anak.

Seiring dengan ini, Ummu Syafa Suryani Arfah dalam bukunya Menjadi Wanita Shalihah, mengatakan bahwa "ibu adalah shibgah (pencelupan) pertama bagi watak dan kepribadian anak. Ia merupakan bayangan yang paling mendekati dengan kepribadian anak, jika ia baik maka akan baik lah anak- anaknya". ${ }^{7}$ Demikian secara tak langsung semua tindak tanduk ibu akan menjadi suri tauladan bagi keluarganya, terutama bagi anak- anaknya karena dari sanalah akan tumbuh kepribadian anak secara bertahap.

Memahami apa yang dijelaskan tersebut, jika benar-benar menjalankan fungsinya dengan baik maka rumah tangga itu akan mampu melahirkan anak sholeh yang kelak menjadi tunas berdirinya

${ }^{5}$ Departemen Agama RI, Al-Qur'an dan Terjemahan, (Jakarta: PT. Bumi Restu), h.951.

${ }^{6}$ Muhammad Ali Hasyimi, Kepribadian Wanita Muslimah Menurut Al-Qur'an dan As-Sunnah, (Jakarta: Akademika Pressindo, 1997), h.195.

${ }^{7}$ Ummu Syafa Suryani Arfah, Menjadi Wanita Shalihah, (Jakarta: Eska Media, 2010), h.272. 
masyarakat yang islami. Juga seorang ibu harus berusaha sedemikian rupa, agar rumah tangganya menjadi terarah dan teratur yang mencerminkan kepribadian islami.

Pada realitasnya banyak ibu yang tidak dapat melaksanakan tugas dan tanggung jawabnya dengan baik di dalam keluarga. Karena ibu tidak pernah tahu bagaimana cara mendidik adnaknya dengan baik seperti sibuk dengan karirnya hingga terkadang menyerahkan tanggung jawab terbesar dalam pendidikan kepada pihak sekolah atau pengasuh anak-anak yang bisa jadi kurang berkualitas. Penyebab lainnya mungkin juga ada yang merasa menyerah dan putus asa dalam mendidik anak karena kurang pengetahuan dan bingung tidak mengerti dengan apa yang harus dilakukan.

Resikonya adalah banyaknya keluarga yang hancur berantakan karena ibu enggan mendidik anak-anaknya, mengabaikan begitu saja, yang akhirnya melahirkan generasi yang tidak dapat diharapkan yaitu generasi yang jahat dan durhaka kepada orang tua dan masyarakat.

Memang ironis sekali, di satu sisi orang tua menginginkan anaknya menjadi anak yang berguna, berbakti, sholih dan sholihah tapi tidak ada persiapan dan pembekalan untuk menjadi orang tua yang baik yang mampu mendidik anaknya dengan penuh ilmu dan cinta. Di sisi lain mereka ibuk di luar rumah dengan pekerjaan sehingga menitipkan anak-anak kepada pembantu, kakek-neneknya atau ke penitipan anak.

\section{PEMBAHASAN}

\section{Peran Ibu sebagai Pendidik}

\section{Pengertian Ibu}

Dalam Kamus Besar Bahasa Indonesia, kata ibu secara etimologi berarti: wanita yang telah melahirkan seseorang, sebutan untuk wanita yang sudah bersuami dan panggilan yang takzim kepada wanita baik yang sudah bersuami maupun yang belum". ${ }^{8}$ Sedangkan di dalam Kamus Lengkap Bahasa Indonesia kata "Ibu berarti emak, orang tua perempuan".

Kata ibu secara terminologi yang dinyatakan oleh Abu Al "Aina Al Mardhiyah dalam bukunya Apakah Anda Ummi Sholihah? Bahwa ibu merupakan status mulia yang pasti akan disandang oleh setiap wanita normal. Ibu merupakan tumpuan harapan penerus generasi, diatas pundaknya terletak suram dan cemerlangnya generasi yang akan lahir. ${ }^{10}$

Alex Sobur dalam bukunya Anak Masa Depan juga mengatakan bahwa ibu adalah orang yang dikejar perhatian. Sebab ia merupakan orang pertama yang dikenal oleh anak, ia menyusukannya dan mengganti pakaiannya. ${ }^{11}$

\footnotetext{
${ }^{8}$ Tim Penyusun Kamus Pusat Bahasa, Kamus Besar Bahasa Indonesia, (Jakarta: Balai Pustaka, 2007), h.416.

${ }^{9}$ Ananda Santoso, Kamus Lengkap Bahasa Indonesia, (Surabaya: Alumni Surabaya), h.156.

${ }^{10} \mathrm{Abu} A \mathrm{Al}$ "Aina Al Mardhiyah, Apakah Anda Ummi Sholihab?, (Solo: Pustaka Amanah, 1996), h.20.

${ }^{11}$ Alex Sobur, Anak Masa Depan, (Bandung: Angkasa, 1986), h.34
} 
Hal ini Suryati Armaiyn dalam bukunya Catatan Sang Bunda mengatakan bahwa:

Ibu adalah manusia yang sangat sempurna. Dia akan menjadi manusia sempurna manakala mampu mengemban amanah Allah. Yaitu menjadi guru bagi anak-anaknya, menjadi pengasuh bagi keluarga, menjadi pendamping bagi suami dan mengatur kesejahteraan rumah tangga. Dia adalah mentor dan motivator. Kata-katanya mampu menggelorakan semangat. Nasihatnya mampu meredam ledakan amarah. Tangisnya menggetarkan arasy Allah. Doanya tembus sampai langit ke tujuh. Di tangannya rejeki yang sedikit bisa menjadi banyak, dan ditangannya pula penghasilan yang banyak tak berarti apa-apa, kurang dan terus kurang. Dialah yang mempunyai peran sangat penting dalam menciptakan generasi masa depan. ${ }^{12}$

Berpijak dari pengertian di atas, dapat disimpulkan seorang ibu adalah segalanya, hampir tidak bisa diungkapkan dengan kata-kata. Seorang ibu tidak akan pernah membuat anaknya kekurangan apa pun. Seorang ibu akan selalu berusaha untuk mewujudkan cita-cita anak-anaknya, seorang ibu akan bekerja bahkan sangat keras untuk memenuhi kebutuhan hidup anaknya tanpa memikirkan dirinya sendiri. Apapun akan dilakukannya, kasih dan sayangnya yang hangat selalu diberikan kepada anaknya. Seorang ibu juga rela kekurangan demi anaknya, tidak ada satu perhatian pun yang luput dari dirinya. Sebab ibulah yang paling dekat dengan anak-anaknya, dikarenakan hubungan emosional dan factor keberadaan seorang ibu bersama anaknya lebih banyak.

\section{Pengertian Pendidikan}

Istilah Pendidik merupakan tenaga profesional yang bertugas merencanakan dan melaksanakan pembelajaran, menilai hasil pembelajaran, melakukan pembimbingan dan pelatihan, serta melakukan penelitian dan pengabdian kepada masyarakat. ${ }^{13}$ Menurut Hery Noer Aly dan Monzier dalam bukunya Watak Pendidikan Islam mengatakan bahwa pendidikan merupakan lingkungan yang paling penting dalam membantu manusia untuk mencapai perkembangannya oleh sebab itu penyelenggaraan pendidikan merupakan suatu keharusan. ${ }^{14}$

Jika dilihat dari sudut etimologis, kata pendidikan dalam bahasa Inggris adalah education. Menurut John Dewey bahwa education is a process of overcoming natural inclination and substituting in its place habits acquired under external pressure. ${ }^{15}$ Artinya pendidikan adalah sebuah proses mengatasi kecenderungan alami (bawaan diri manusia yang buruk) dan menggantinya ke dalam kebiasaan yang diperoleh di bawah pengaruh dari luar (pembelajaran).

Seiring dengan itu, Djumransjah dkk. dalam bukunya Pendidikan Islam Menggali Tradisi Mengukubkan Eksistensi mengatakan bahwa: mendidik atau pendidikan adalah menumbuhkan dan mengembangkan potensi jasmaniah dan rohaniah anak didik atau seseorang untuk mendapatkan nilai-nilai dan norma-norma tertentu. Kegiatan pendidikan tersebut dapat berlangsung di dalam keluarga, sekolah dan masyarakat, lembaga-lembaga tersebut yang ikut

\footnotetext{
${ }^{12}$ Suryati Armaiyn, Catatan Sang Bunda, (Jakarta: Al-Mawardi Prima Jakarta, 2011), h.7-8

${ }^{13}$ Undang-undang Guru dan Dosen, (Yogyakarta: Pustaka Pelajar, 2009), h.3.

${ }^{14}$ Hery Noer Aly dan Moenzier, Watak Pendidikan Islam, (Jakarta: Fisika Agung Lestari, 2000), h.130.

15John Dewey, Experience and Education, (New York: Touchstone Rockefeller Center, 1997), h. 17.
} 
bertanggung jawab memberi pertolongan kepada anak didik dalam perkembangan rohani dan jasmaninya, agar mencapai tingkat kedewasaan dan mampu berdiri sendiri memenuhi tugasnya sebagai makhluk Allah, makhluk sosial dan sebagai individu. ${ }^{16}$

Menurut Syed Muhammad Naquib al-Attas mengatakan the literal meaning is : bestow on them mercy

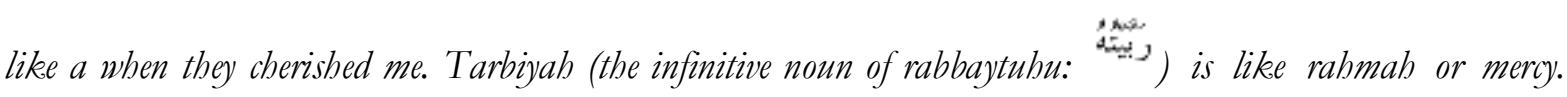
When it is God Who creates, nourishes, sustains, provides, cherishes and possesses, such acts, by which God is called al-rabb, are acts of rahmah or mercy. When it is man who by analogy does similar acts to his offspring, it is called tarbiyah.

Artinya secara harfiah: berikan kepada mereka rahmat seperti ketika mereka saya. Tarbiyah

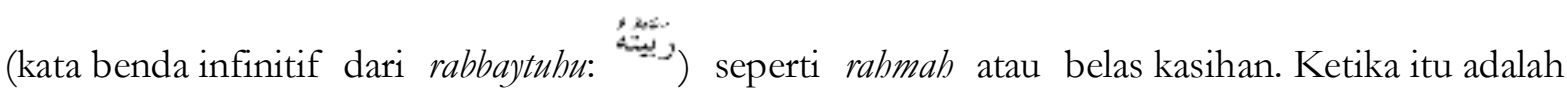
Allah yang menciptakan, memelihara, menopang, menyediakan, menghargai dan memiliki, tindakan seperti itu, dimana Allah disebut al-rabb, adalah memberikan rabmah atau belas kasihan. Ketika itu adalah orang yang dengan analogi melakukan tindakan serupa terhadap keturunannya, hal itu disebut tarbiyah. ${ }^{17}$

Pendidikan Islam adalah pendidikan yang bersumber pada pendidikan yang diberikan Allah sebagai "pendidik" seluruh ciptaan-Nya, termasuk manusia. Menurut Abdurrahman An-Nahlawi yang dikutip oleh Samsul Nizar menjelaskan bahwa dalam konteks yang luas, pengertian pendidikan Islam yang dikandung dalam term al-tarbiyah terdiri atas empat unsur pendekatan, yaitu: (1) memelihara dan menjaga fitrah anak didik menjelang dewasa (baligh). (2) mengembangkan seluruh potensi menuju kesempurnaan. (3) mengarahkan seluruh fitrah menuju kesempurnaan. (4) melaksanakan pendidikan secara bertahap. ${ }^{18}$

Pendidikan juga diartikan sebagai sebuah proses memanusiakan manusia sejak masa kejadiannya sampai akhir hayatnya melalui berbagai ilmu pengetahuan yang disampaikan dalam bentuk pengajaran secara bertahap, di mana proses pengajaran itu menjadi tanggung jawab orang tua dan masyarakat menuju pendekatan diri kepada Allah sehingga menjadi manusia sempurna. ${ }^{19}$

\section{Peran Ibu Sebagai Pendidik}

Menilik penjelasan di atas sejatinya ibu dikatakan ideal dalam Islam yaitu mampu mendidik anak dengan nilai ke-Islaman sejak masih dini, memiliki budi pekerti yang baik (akblakul karimah), selalu h.85.

${ }^{16}$ Djumransjah, Pendidikan Islam Menggali Tradisi Mengukubkan Eksistensi, (Malang: UIN-Malang Press, 2007), 32.

${ }^{17}$ Syed Muhammad Naquib al-Attas, The Concept of Education In Islam, (Malaysia: Art Printing Work, 1991), h.

${ }^{18}$ Samsul Nizar, Filsafat Pendidikan Islam, Pendekatan Historis, Teoritis dan Praktis, (Jakarta: Ciputat Press, 2002), h. 26 .

${ }^{19}$ Abidin Ibnu Rusn, Pemikiran Al-Ghazali Tentang Pendidikan, (Yogyakarta: Pustaka Pelajar, 2009), h. 56. 
menjaga perilakunya agar menjadi teladan bagi anaknya, memiliki sikap penyabar, sopan serta lembut dalam berbicara agar kelak sang anak dapat memiliki kepribadian yang tangguh dan baik.

Tidak ada yang meragukan betapa pentingnya ibu dalam pendidikan anak seperti kasih sayang dan perhatian dari seorang ibu. Karena perhatian dan kasih sayang tersebut akan menimbulkan perasaan diterima dalam diri anak-anak dan membangkitkan rasa percaya diri di masa-masa pertumbuhan mereka.

Hal ini dipertegas oleh Lidya Yurita dalam bukunya Mukjizat Doa Ibu! Yang mengatakan bahwa " ibu muncul sebagai sosok yang siap siaga dan serba bisa. Kasih sayang, kelembutan dan perhatiannya menempatkan ibu menjadi sosok yang dibutuhkan seluruh anggota keluarga". ${ }^{20}$ Begitu juga, dalam bukunya Khairiyah Husain Thaha yang berjudul Konsep Ibu Teladan yang menyatakan bahwa: Orang tua terutama ibu yang banyak bergulat dengan anak, mempunyai tugas yang amat besar untuk mendidik anak baik pendidikan jasmani, intelektual dan mental spiritual, sehingga melalui teladan yang baik atau pelajaran yang berupa nasehat-nasehat, kelak ia dapat memetik tradisi-tradisi yang benar dan pijakan moral yang sempurna dari masa kanakkanaknya. ${ }^{21}$

Dalam Kamus Bahasa Indonesia Lengkap kata peran berarti Pemain sandiwara (film), Tukang lawak pada permainan makyong dan Perangkat tingkah yang diharapkan dimiliki oleh orang yang berkedudukan di masyarakat". ${ }^{22}$

Adapun di dalam buku Kamus Bahasa Indonesia Lengkap kata "peran berarti yang diperbuat, tugas, hal yang besar pengaruhnya pada suatu peristiwa." ${ }^{23}$ Jadi, peran adalah seperangkat tingkah laku yang diharapkan oleh orang lain terhadap kedudukan dalam peristiwa dan peristiwa membutuhkan sentuhan atau tindakan seseorang yang dapat mengelola, menjaga, merubah dan memperbaiki suatu peristiwa. Dengan ini, sebuah peristiwa membutuhkan peran dari seseorang yang mana, peran juga dipengaruhi oleh keadaan sosial baik dari dalam maupun dari luar yang bersifat stabil.

Jika dikaitkan dengan pengertian ibu dengan perannya, pada umumnya ibu yang memegang peran penting terhadap pendidikan anak-anaknya sejak anak itu dilahirkan. Ibu yang selalu di samping anak, itulah sebabnya kebanyakan anak lebih dekat dan sayang kepada ibu. Tugas seorang ibu sungguh berat dan mulia, ibu sebagai pendidik dan sebagai pengatur rumah tangga. Hal ini amatlah penting bagi terselenggaranya rumah tangga yang sakinah yaitu keluarga yang sehat dan bahagia, karena dibawah perannya lah yang membuat rumah tangga menjadi surga bagi anggota keluarga, menjadi mitra sejajar yang saling menyayangi bagi suaminya. Sehingga untuk mencapai ketentraman dan kebahagiaan dalam keluarga dibutuhkan ibu sholehah, yang dapat mengatur keadaan rumah menjadi tempat yang menyenangkan, memikat hati seluruh anggota keluarga.

\footnotetext{
${ }^{20}$ Lidia Yunita, Mukjizat Doa Ibu!, (Jogjakarta: Diva Press, 2009), h.190

${ }^{21}$ Khairiyah Hasain Thaha, Konsep Ibu Teladan, (Surabaya: Risalah Gusti, 1992), h.5

${ }^{22}$ Tim Penyusun Kamus Pusat Bahasa..., h.854.

${ }^{23}$ Daryanto, Kamus Babasa Indonesia Lengkap, (Surabaya: Apollo, 1997), h.487.
} 
Hal ini dipertegas oleh pendapat Norma Tarazi dalam bukunya Wabai Ibu Kenali Anakmu yang mengatakan bahwa: "peran seorang ibu yang bijaksana akan mengevaluasi keadaanya dengan seksama, menimbang usaha dan keuntungan dalam mengasuh anak dan merawat rumah. Keadaanya yang terdahulu harus menjadi dasar, ukuran dan landasan bagi tanggung jawabnya memenuhi hak-hak setiap anggota keluarga". ${ }^{24}$

Khabib Ahmad Shanthut dalam bukunya Menumbubkan Sikap Sosial, Moral dan Spiritual Anak. dalam Keluarga Muslim yang mengatakan bahwa: "peran seorang ibu itu senantiasa mempersiapkan diri untuk mengasuh anak dan rela berkorban untuknya baik di waktu istirahat atau sibuk. Dia akan tetap sabar. Sikap pengasih inilah yang sering membuat ibu tidak dapat tidur meskipun anaknya terlelap." 25

Menurut hemat penulis, bahwa ibu dan perannya terhadap anak adalah sebagai pembimbing kehidupan di dunia ini, seorang Ibu merupakan salah satu dari kedudukan sosial yang mempunyai banyak peran, peran sebagai istri dari suaminya, sebagai ibu dari anak-anaknya. Ibu juga berfungsi sebagai benteng keluarga yang menguatkan anggota-anggota keluarganya, serta mempunyai peran dalam proses sosialisasi dalam keluarga. Jadi peran ibu adalah tingkah laku yang dilakukan seorang ibu terhadap keluarganya untuk merawat suami dan anak-anaknya.

Adapun di dalam menjalankan peran, ibu harus membekali dirinya sebaik mungkin dengan bekal yang bisa membantunya dalam memainkan peran yang amat penting. Yaitu dalam membimbing anak dengan bimbingan yang bisa menjaga anak dari keburukan dan terbentuklah pribadi yang shaleh. Hal ini pun dipertegas oleh Lydia Harlina Martono, dkk dalam bukunya mengasub Anak dalam Keluarga yang mengatakan bahwa: "mengasuh dan membimbing Anak ialah mendidik anak agar kepribadian anak dapat berkembang dengan sebaik-baiknya, sehingga menjadi manusia dewasa yang bertanggung jawab. ${ }^{26}$

Menjadi ibu yang baik bagi anak memerlukan perencanaan dan tindak lanjut, agar ibu dapat melakukan pengasuhan yang di dalamnya memenuhi karakteristik baik bagi seorang ibu, sehingga ibu mampu mengembangkan karakter yang baik, di antaranya:

\section{a. Keharusan mengenali diri}

Bagi seorang ibu, mengenali diri sendiri amat penting mulai dari kekuatan, kelebihan, kemampuan serta kekurangan bahkan kelemahan yang ada di dalam dirinya. Mengenali diri sendiri yang ada di dalam jiwa ibu sama hal nya dengan mengenal Allah SWT, karena dengan mengenal Allah SWT seorang ibu akan menjunjung tinggi nilai-nilai ketakwaan, kemanusiaan, dan kemuliaan yang akhirnya karakter ibu yang baik akan menjiwai anak dengan baik pula.

${ }^{24}$ Norma Tarazi, Wahai Ibu Kenali Anakmu, (Yogyakarta: Mitra Pustaka, 2001), h.83.

${ }^{25}$ Khabib Ahmad Santhut, Menumbubkan Sikap Sosial Moral dan Spiritual Anak dalam Keluarga Muslim, (Yogyakarta: Mitra Pustaka, 1998), h.18.

${ }^{26}$ Lydia Harlina Martono, dkk, Mengasuh dan Membimbing Anak dalam Keluarga, (Jakarta: PT Pustaka Antara, 1996), h.10. 


\section{b. Menyadari Pentingnya Pembangunan Karakter}

Pada dasarnya ibu berpijak di dunia ini bukan untuk berdiam diri saja. Melainkan seorang ibu bertanggung jawab terhadap pentingnya pembangunan yaitu membangun anak. Tentunya untuk membangun anak yang shaleh, ibu tidak berjuang sendiri perlu bantuan orang lain. Dan ibu tidak akan menyerah dengan segenap kesulitan hidup yang ibu hadapi.

\section{c. Pentingnya ketakwaan bagi ibu}

Penting sekali bagi seorang ibu memiliki ketakwaan kepada Allah SWT, ibu harus terus merasakan akan hadirnya Allah SWT dalam dirinya, agar dapat mencegah beberapa persoalan yang dihadapi dalam kehidupannya. Dengan begitu, ibu bisa terhindar dari segala kesulitan dan mencegah penyakit jiwa. Seorang ibu juga merupakan sumber teladan bagi keluarga terutama anak. Maka pentingnya ketakwaan bagi ibu akan mempengaruhi jiwa anak kelak.

\section{d. Pentingnya pendidikan menjadi ibu}

Penting sekali seorang ibu memiliki pendidikan yang benar sesuai dengan akidah Islam. Karena dengan ibu mendidik anak secara Islam, maka anak-anak pun menjadi generasi yang baik. Dan sebaliknya, bila ibu tidak mau mengerti akan pentingnya pendidikan baginya, alhasil harapan menggapai anak shaleh, berilmu dan berkualitas tidak akan terwujud. Pendidikan anak bisa dimulai oleh ibu melalui pengalaman, kebiasaan dan tradisi.

e. Aspek Agama, moral, etika dan tradisi

Dari ketiga aspek ini, kesemuanya memiliki hubungan yang erat dan pantas dimiliki oleh seorang ibu. Jika ibu berpijak pada agama, moral pun ikut berperan. Dan apabila seorang ibu tidak mempunyai landasan agama dan moral, bagaimana mungkin seorang ibu mendidik anak dengan baik. Maka aspek agama dan moral lah sangat berhubungan erat terhadap perkembangan spiritual dan moral bagi anak. Begitu juga dengan aspek etika dan tradisi. Karena seorang ibu tidak mungkin hidup bermasyarakat dan bergaul kepada sesama hanya mengandalkan aspek agama dan moral saja. Ibu pun harus memiliki aspek etika dan tradisi, agar terjalin tatakrama yang baik. Sehingga ini menjadi contoh bagi anak, dan anak pun mengikuti dengan baik.

\section{f. Aspek bahasa dan pengetahuan umum}

Sejak kecil, ibu sudah mengajarkan anak berbicara dengan mengucapkan kata-kata. Memang sudah sepantasnya ibu menjadi guru yang pertama dan utama bagi anak, karena disitu ibu menjadi tempat bercurah kasih dan tempat menanya di kala anak tak mengetahui sesuatu. Maka dengan memiliki ke semua itu baik bahasa maupun pengetahuan umum, niscaya ibu akan melahirkan anak yang unggul terhadap masyarakat

g. Pengetahuan kesehatan

Seorang ibu wajib mengetahui kesehatan terhadap anak. Dan jikalau anak sakit, setidaknya ibu bisa memberikan pertolongan pertama serta pengobatan terhadap anak sebelum dibawa ke dokter.

h. Mengatur rumah tangga dan aspek ketrampilan 
Dalam berumah tangga, ibu harus paham betul bagaimana mengatur rumah tangga yang baik serta seni ketrampilan apa saja yang pantas ibu miliki. Seperti mengatur, merawat, membersihkan dan menyusun perabotan yang ada di rumah dengan penataan yang baik, dengan begitu anak akan betah tinggal di rumah. ${ }^{27}$

Dari penjelasan di atas, dapat penulis simpulkan bahwa peran pendidikan seorang ibu adalah di antaranya mendidik anak dengan mengasihi dan menyayangi, membimbing anak dengan sebenar-benarnya serta mengarahkan anak dengan penuh kesadaran dan ini sangat penting sekali diterapkan oleh ibu, agar terwujud dan terbentuklah pribadi yang baik, yaitu anak yang sholeh.

\section{A. Ibu sebagai Pendidik Anak dalam Keluarga}

Keluarga adalah merupakan lingkungan pertama bagi anak untuk memperoleh pendidikan. Ayah dan ibu sebagai pendidiknya dan anak sebagai peserta didiknya. Keluarga sebagai satuan unit sosial terkecil merupakan lingkungan pendidikan yang paling utama dan pertama. Ini artinya bahwa keluarga merupakan lingkungan yang paling bertanggung jawab untuk mendidik anak- anak. Mendidik anak pada hakekatnya merupakan usaha riil orang tua untuk mengembangkan potensipotensi yang ada pada diri. ${ }^{28}$

Keluarga merupakan lembaga pendidikan tertua, bersifat informal, yang pertama dan utama dialami oleh anak serta lembaga pendidikan yang bersifat kodrati, orang tua bertanggung jawab memelihara, merawat, melindungi dan mendidik agar tumbuh dan berkembang dengan baik. ${ }^{29}$ Proses pendidikan dalam keluarga dilakukan dengan cara memberikan pengarahan baik dalam bentuk nasihat, perintah, larangan, pembiasaan, pengawasan, dan pemberian ilmu pengetahuan. ${ }^{30}$ Anak mendapat bimbingan dan perawatan dalam rangka membentuk perwatakan dan kepribadian anak.

\section{Ibu Sebagai Teladan dan Anak dalam Keluarga}

Dalam menyikapi dan mengarahkan anak, seorang ibu sebagai teladan harus mampu menjadi teladan bagi anak-anaknya. Mengingat bahwa perilaku ibu akan ditiru dan akan dijadikan panduan anak, maka ibu harus mampu menjadi teladan yang baik bagi anak, dengan begitu terbentuklah kepribadian anak yang baik. Hal ini pun dipertegas Charles Schaefer dalam bukunya Bagaimana Mempengarubi Anak yang mengatakan bahwa "perilaku yang kuat dalam memberikan pendidikan terhadap anak adalah teladan orang tua". ${ }^{31}$

Seiring dengan itu ditemui dalam buku Muhyiddin Abdul Hamid dalam bukunya Kegelisahan Rasulullah Mendengar Tangis Anak yang mengatakan bahwa "perilaku keseharian orang tua

${ }^{27}$ Ali Qaimi, Buaian Ibu...,h.40-52.

${ }^{28}$ Maimunah Hasan, Pendidikan Anak Usia Dini, (Yogyakarta: Diva Pres, 2010), h.24.

${ }^{29}$ Binti Maunah, Landasan Pendidikan, (Yogyakarta: Teras, 2009), Cet.I, h.178

${ }^{30}$ Novan Ardy Wiyani dan Barnawi, Ilmu Pendidikan Islam: Rancang Bangun Konsep Pendidikan MonokotomikHolistik, h.56.

${ }^{31}$ Charles Schaefer, Bagaimana Mempengarubi Anak, (Semarang: Dahara Prize, 1994),h.16. 
yang disaksikan dan dirasakan anak termasuk hal yang memiliki bekas dan pengaruh tersendiri di dalam jiwa dan kepribadian anak. Sehingga dari interaksi sehari-hari antara orang tua dan anak terjadi proses peneladanan (modeling)" ${ }^{32}$

Menurut Suryati Armaiyn dalam bukunya Catatan Hati Sang Bunda yang mengatakan bahwa "seorang ibu, sebagaimana juga ayah, haruslah menjadi teladan bagi anak- anaknya. Sebab kedua orang tualah yang paling dekat dengan mereka dibandingkan siapapun. Dan cara atau metode terbaik untuk pendidikan anak di dalam keluarga adalah keteladanan. ${ }^{33}$

Dari beberapa pendapat di atas, berpendapat di antaranya adalah: pertama Charles Scaefer menyatakan bahwa dalam menumbuhkan perilaku kepada anak, teladan orang tua lah yang amat kuat mempengaruhi. Kedua; Muhyiddin Abdul Hamid menjelaskan perilaku keseharian orang tua dapat menumbuhkan proses peneladanan. Ketiga: Suryati Armaiyn mengatakan bahwa metode terbaik untuk anak adalah teladan orang tua. Adapun persamaannya bahwa pengaruh dari keteladanan orang tua akan berdampak pada perilaku keseharian anak-anak dalam hidupnya.

Menurt penjelasan di atas, penulis dapat menganalisa bahwa ibu sebagai teladan bagi anak di dalam keluarga memang sangat penting dilakukannya untuk membentuk kepribadian anak yang baik, apalagi seorang anak yang mana segala sikap, prilaku dan perbuatan ibu sangat mudah ditiru olehnya.

Berbicara mengenai contoh yang baik bagi anak, ibu sebagai teladan anak, yang mana kondisi anak masih tabu serta peka dengan hal-hal atau kegiatan sehari-hari yang anak lihat dan saksikan dari orang terdekatnya. Dengan begitu, teladan serta contoh yang baik akan memberikan pengaruh kepada anak dengan baik pula. Dan teladan yang baik itu dialah rasulullah SAW. Beliau merupakan teladan umat muslim sedunia yaitu insan yang paling sempurna akhlaknya.

Sebagaimana Allah SWT berfirman dalam surat al-Ahzab ayat 21:

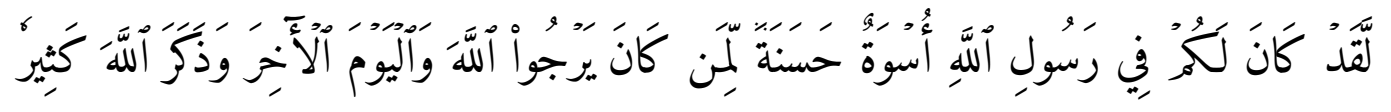

Sesunggubnya telah ada pada (diri) Rasulullah itu suri teladan yang baik bagimu (yaitu) bagi orang yang mengharap (rahmat) Allah dan (kedatangan) hari kiamat dan dia banyak menyebut Allah.

Perintah ini ditujukan kepada kaum muslimin di dunia, bahwa Allah SWT mengutus kekasihnya yaitu Rasulullah SAW sebagai pembawa perubahan akhlak yang baik, serta keteladanan beliau pantas di tiru oleh ummat-Nya. Namun, dalam hal ini sosok ibu sebagai teladan lah yang menjadi fondasi utama bagi anak, karena dengan ibu meneladani Rasulullah SAW baik sikap, perilaku, akhlak serta bagaimana memberikan contoh yang baik dalam Islami kepada anak. Maka terbentuk lah anak sholeh yang memiliki kepribadian baik. Dan itu semua bisa terwujud dengan meniru figure Rasulullah SAW dengan baik pula.

\footnotetext{
${ }^{32}$ Muhyiddin Abdul Hamid, Kegelisahan Rasulullah Mendengar Tangis Anak, (Semarang: Dahara Prize, 1994), h.16.
}

${ }^{33}$ Suryati Armaiyn, Catatan Sang Bunda..., h.54. 
Hal ini dipertegas oleh Muhyiddin Abdul Hamid dalam bukunya Kegelisahan Rasulullah mendengar Tangis Anak yang mengatakan bahwa:

Orang tua yang bijaksana mesti memperkenalkan anak- anaknya agar terjadi ikatan dengan sang suri tauladan yang baik, yang telah diutus oleh Allah SWT untuk menyempurnakan serta meluruskan dekadensi moral orang-orang jahiliyah. Beliau adalah siraj al-munir (lampu penerang) yang perkataan dan tingkah lakunya telah mendapat bimbingan langsung dari Allah SWT. Akhlak dan kepribadian beliau adalah al-Qur"an. Semua gaya hidup beliau perlu di informasikan kepada anak-anak agar secara berangsur angsur mereka bisa meneladani dan memiliki kepribadian beliau. ${ }^{34}$

Hal senada juga dijelaskan oleh Norma Tarazi dalam bukunya Wahai Ibu Kenali Anakmu mengatakan bahwa:

Orang tua yang benar-benar bertakwa senantiasa menyayangi anak-anaknya dengan memenuhi kebutuhannya baik fisik maupun emosional, memberi pelajaran, latihan, nasihat, arahan dan bimbingan, semua ini adalah tugas orang tua yang sangat mendasar. Contohlah akhlak mulia kepribadian, tindakan dan tutur kata Rasulullah SAW, sosok teladan dengan segala hal. ${ }^{35}$

Dari beberapa pendapat di atas, perbedaan di antara keduanya adalah: pertama Muhyiddin Abdul Hamid menjelaskan bahwa Rasulullah SAW sebagai siraj al-munir (lampu penerang), dengan keteladananya orang tua perlu memperkenalkannya kepada anak, agar anak memiliki ikatan batin serta meneladani nya dengan baik. Kedua: Norma Tarazi menyatakan bahwa tugas utama orang tua adalah memberikan teladan yang baik seperti teladan Rasulullah SAW adalah teladan paripurna yang perlu dicontoh oleh orang tua untuk membentuk perilaku anak yang baik.

Penulis dapat menganalisis, sebagai teladan bagi anak-anaknya sebaiknya meneladani figur Rasulullah SAW dengan baik, bukan hanya memerintah dan menyalahkan, akan tetapi yang lebih penting adalah memberikan contoh konkret dalam sikap, perilaku serta akhlak yang baik. Sehingga terbentuklah kepribadian anak yang baik dan ber akhlakul karimah.

Dalam memberikan teladan kepada anak secara Islami, Rasulullah SAW sangat terkenal memberikan contoh dengan sikap penyayang, lemah lembut dan pemerhati pada setiap anak kecil. Oleh karena itu, peran ibu sebagai teladan, patut menjadikan figur Rasulullah SAW lah yang menjadi panutan berharga dalam memberikan contoh kepada anak secara Islam.

\section{Ibu Sebagai Pembina Anak dalam keluarga}

Dalam membina anak, tentu sosok ibu merupakan sosok yang pertama kali dikenali oleh anak, yang mana ibu berperan sebagai Pembina memberikan arahan-arahan atau bimbingan Islami kepada anak, dengan tujuan dapat membina anak agar memiliki kepribadian yang baik. Pada umumnya, ibu sebagai Pembina anak sangat dekat dengan anak-anaknya dan disenangi oleh anakanak pula. Karena kepadanyalah anak-anak mengungkapkan perasaan, permasalahan kemudian

\footnotetext{
${ }^{34}$ Muhyiddin Abdul Hamid, Kegelisahan Rasulullah Mendengar Tangis Anak..., h.215.

${ }^{35}$ Norma Tarazi, Wahai Ibu Kenali Anakmu..., h.145-146.
} 
sang ibu pun langsung bergerak serta berusaha mengatasi perasaan anak-anak dengan semampu dan semaksimal mungkin.

Melihat anak-anak yang sangat dekat dengan ibu, maka harapan dari ibu sebagai Pembina yakni secara garis besar ingin menjadikan anak-anaknya memiliki kepribadian yang shaleh dan baik, dengan cara membentengi anak-anak dengan nilai-nilai Islami.

Adapun untuk membentengi anak-anak pada nilai-nilai yang islami, maka ibu sebagai Pembina perlu membina anak-anak dengan pendidikan-pendidikan yang Islami pula. Dengan begitu, anak akan terus berjalan dengan baik, serta memiliki kepribadian yang shaleh.

Hal ini dipertegas oleh Ray Sitoresmi Prabuningrat dalam bukunya Sosok Wanita Muslimah yang mengatakan bahwa:

Dalam rangka pendidikan. Saya percaya bahwa kaum ibu memang melebihi kaum pria. Dalam kaitan ini saya berharap agar kepribadian juga memancarkan segi pendidikan bagi keluarga dan lingkungan kita. Keseluruhan penampilan wanita muslimah yang ideal hendaknya berkaitan dengan pendidikan yang ditujukan kepada anak-anak dan juga lingkungan sekitar. ${ }^{36}$

Sesungguhnya menanamkan pendidikan Islam kepada anak-anak merupakan tanggung jawab bersama antara suami-istri. Dalam hal ini istrilah yang lebih dekat dengan anak-anak ketika masih balita. Istri harus menanamkan pada mereka ajaran-ajaran Islam, melatih dan membiasakan mereka melakukan sesuatu sesuai hukum-hukum Islam dan menghias diri dengan akhlak mulia. ${ }^{37}$

Adapun Khairiyah Husain Thaha dalam bukunya Konsep Ibu teladan menyatakan bahwa Islam memandang masa bayi dan kanak-kanak sebagai masa yang menjadi dasar bagi Pembinaan kepribadian dan kesuksesan anak di masa depan. Karenanya ibu sebagai Pembina anak perlu menumbuh kembangkan ilmu pengetahuan berupa pendidikan-pendidikan Islami, dan kesemuanya dapat ditempuh melalui:

a. Pendidikan jasmani maksudnya, ibu sebagai Pembina tidak hanya mengembangkan otot-otot dan tenaga saja pada anak, melainkan ibu harus memperhatikan potensi-potensi biologis yang tumbuh dari jasmaninya. Apalagi anak yang masih balita yang amat rentang dengan kesehatan, seperti ibu memperhatikan dalam pola makanan bagi anak. Karena patut dicatat makanan amat penting bagi tumbuh kembangnya anak, seorang ibu juga, harus benar-benar memperhatikan kebutuhananak waktu, cara tidur yang baik. Karena tidur merupakan kebutuhan yang berpengaruh pada pertumbuhannya, dengan cara anak dibiasakan tidur berbaring di sisi kanan. Begitupun ibu harus memperhatikan kebutuhan pakaian dan cara mengenakannya, yaitu anak dibiasakan untuk memulainya dari sebelah kanan atau dengan tangan kanan. h.17.

${ }^{36}$ Ray Sitoresmi Prabuningrat, Sosok Wanita Muslimah, (Yogyakarta: PT Tiara Wacana Yogya, 1997),

${ }^{37}$ Mahmud Al-Shabbagh, Tuntunan Keluarga Bahagia Menurut Islam, (Bandung: PT Remaja Rosdakarya, 1991), h.156. 
Ibu juga harus melatih anak-anak dengan permainan- permainan olahraga yang menyehatkan dan menyegarkan seperti lari, dan berenang.

b. Pendidikan intelektual maksudnya, ibu sebagai Pembina intelektual perlu mengajar dan membiasakannya untuk menimba sebagai sumber peradaban dan sains dan mengarahkannya untuk mempelajari al-Qur"an serta sejarah kenabian di usia dini. Sebagaimana Al-ghazali dalam melatih anak-anak untuk menghafal al-Qur"an sejak dini, karena anak yang masih kecil itu bagaikan kertas kosong, yang bisa diisi dengan berbagai tulisan.

c. Pendidikan ruhani maksudnya, di dalam jiwa manusia terdapat potensi yang kuat yaitu potensi rabbani yang bisa mempertemukan antara sang khaliq (Allah SWT) dengan manusia.

Sebagaimana Allah SWT berfirman dalam surat Al-Hijr 29:

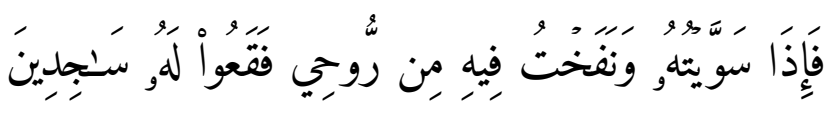

Maka apabila Aku telah menyempurnakan kejadiannya, dan telah meniup kan kedalamnya ruh (ciptaan)-Ku, maka tunduklah kamu kepadanya dengan bersujud.

Ayat ini menjelaskan kepada setiap manusia, bahwa setelah Allah SWT memberikan kesempurnaan atas penciptaannya kepada manusia dengan meniupkan ruh kepada manusia. Maka Allah SWT menyuruh kepada manusia untuk tunduk kepada-Nya dengan menaati perintah dan larangan-Nya serta kebesaran yang Allah SWT miliki, sehingga terjadilah potensi yang kuat antara manusia dengan sang khaliq (Allah SWT).

Adapun ibu sebagai pembina pendidikan ruhani pada anak, ajaklah anak untuk menikmati alam sekitar dengan merenungkan dan menghayati kebesaran Allah dalam penciptaan- Nya. Dengan begitu, timbul pada diri anak bahwa kebesaran Allah SWT perlu direalisasikan dengan semata-mata ibadah pada Allah SWT, tentunya dengan binaan ibu. ${ }^{38}$ Sedangkan Wahid Abdus Salam Bali dalam bukunya Kiat Mencetak Anak Shalih mengatakan bahwa dalam membina kepribadian anak shaleh agar memiliki kemuliaan iman, perlu peran seorang ibu sebagai Pembina untuk mengarahkan anak-anak pada pendidikan-pendidikan Islam diantaranya:

1. Pendidikan iman maksudnya, seorang ibu sebagai pembina anak dapat membiasakan anak-anak dengan dasar-dasar keimanan, seperti mengenalkan dan mengajarkan iman kepada Allah SWT, iman kepada malaikat, iman kepada kitab-kitab Allah SWT, iman kepada malaikat, iman kepada kitab-kitab Allah SWT, iman kepada rasul, iman kepada hari kiamat dan iman kepada qada serta qadar. Begitu juga dengan rukun- rukun Islam seperti membaca dua kalimat syahadat, shalat, puasa, zakat dan pergi haji bila mampu.

2. Pendidikan moral maksudnya, ibu sebagai Pembina perlu membina anak-anak pada pendidikan moral yaitu akhlak. Bila sejak dini ibu sudah membina anak-anak beriman kepada Allah

${ }^{38}$ Khairiyah Husain Thaha, Konsep Ibu Teladan ..., h.69-76. 
SW'T yang terdidik untuk takut kepada-Nya serta merasa diawasi segala bentuk perbuatannya oleh Allah SWT, niscaya anak-anak pun terbiasa melakukan akhlak yang utama dan mulia. ${ }^{39}$

Sama halnya dengan Fuad Kauma dan Nipan dalam bukunya Membimbing Istri Mendampingi Suami menyatakan bahwa ibu sebagai Pembina dalam keluarga perlu pendidikan- pendidikan yang islami di antaranya:

a. Pendidikan aqidah maksudnya, pada dasarnya setiap anak yang lahir di dunia ini sudah memiliki benih aqidah yang benar, akan tetapi aqidah itu akan tumbuh dan mengakar kuat pada diri anak, jika ada peran dari seorang ibu sebagai Pembina yang paham akan hal itu. Namun sebaliknya, jika ibu membina anak-anak ke arah yang tidak tepat, maka tersesatlah anak dan benih akidah pun akan layu begitu saja. Dengan begitu, ibu sebagai Pembina yang dekat dengan anak sebaiknya anak-anak dari kecil sudah dikenalkan rukun iman yang enam, agar kelak tumbuh menjadi pribadi yang baik.

b.Pendidikan ibadah maksudnya, setelah anak-anak mengetahui dan memahami dengan pendidikan aqidah, maka anak-anak pun perlu merealisasikan dalam bentuk ibadah. Karena aqidah tidak hanya diyakini saja, melainkan harus dikerjakan dalam ibadah. Adapun bentuk-bentuk dari ibadah seperti shalat. Sebagai Pembina dalam ibadah shalat, ibu wajib mengenalkan dan membina anak sejak dini agar anak sepanjang hidupnya terbiasa untuk melakukannya tanpa paksaan dan semata-mata mencari ridho Allah SWT, sehingga dalam hidupnya sudah menjadi suatu kebutuhan di dalam dirinya. Demikian juga bentuk-bentuk dari ibadah lainnya.

c. Pendidikan akhlak maksudnya, di dalam Islam perlu menjaga hubungan yang baik antara sesama manusia, dan itu bisa terwujud jika masing-masing saling menghiasi diri dengan akhlak yang mulia. Dan ibu sebagai Pembina, wajib membina anak-anak sejak dini dengan sikap, perilaku dan berkepribadian baik agar anak-anak dapat berbakti kepada orang tua, menghormati orang-orang yang lebih tua, menyayangi orang-orang yang lebih muda serta bisa menjaga diri dari pergaulan sehari-hari.

d. Pendidikan ekonomi maksudnya, dalam Islam perlu adanya keseimbangan, tidak hanya meraih kebahagiaan di akhirat saja, melainkan kebahagiaan di dunia pun perlu dicari. Tentunya dengan cara-cara yang terpuji tanpa harus membuat kerusakan

Sebagaimana Allah SW'T berfirman dalam surat Al-Qashash ayat 77:

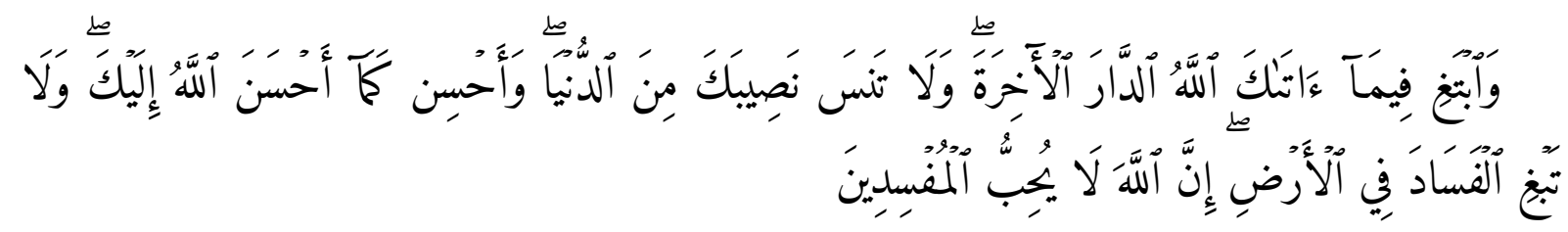

${ }^{39}$ Wahid Abdus Salam Bali, Kiat Mencetak Anak Shalih, (Yogyakarta: Titian Ilahi Press, 2000), h.34-38. 
Dan carilah pada apa yang telah dianugerahkan Allah kepadamu (kebahagiaan) negeri akhirat, dan janganlah kamu melupakan bahagianmu dari (kenikmatan) duniawi dan berbuat baiklah (kepada orang lain) sebagaimana Allah telah berbuat baik, kepadamu, dan janganlah kamu berbuat kerusakan di (muka) bumi. Sesungguhnya Allah tidak menyukai orang-orang yang berbuat kerusakan.

Ayat ini menjelaskan bahwa Allah SWT menghimbau kepada umat manusia untuk hidup dalam keseimbangan antara bahagia di dunia dan akhirat. Tidak hanya mengejar akhirat saja untuk masuk surge, melainkan usaha serta kerja keras pun ditempuh, agar kehidupan ekonomi pun bisa diraih dengan baik dan berkah. Adapun sebagai ibu, jangan sampai anak-anak hidup terlantar karena ibu tidak bisa membina anak-anak dalam masalah ekonomi dengan baik. Untuk itu peran ibu sebagai pembina dengan membina anak hidup mandiri tanpa sering bergantung kepada orang lain, juga anak dibiasakan sejak kecil hidup berkecukupan dengan berhemat dan memanfaatkan sesuatu yang sudah ada tidak berlebih-lebihan. ${ }^{40}$

Dari beberapa penjelasan di atas, perbedaan di antaranya adalah: pertama Ray Sitoresmi Prabuningrat menjelaskan bahwa dalam segi pendidikan, keseluruhan penampilan wanita muslimah yang ideal ditujukan untuk anak. Kedua: Mahmud Al-Shabbagh menyatakan bahwa menanamkan pendidikan Islam kepada anak, merupakan tanggung jawab suami istri. Ketiga: Khairiyah Husein Thaha mengatakan bahwa dalam membina, pendidik perlu mempertimbangkan dengan pendidikan jasmani, pendidikan intelektual dan pendidikan ruhani. Keempat: Wahid Abdus Salam bali menyatakan bahwa pendidikan Islam yang ditujukan kepada anak yaitu pendidikan iman dan moral. Dan kelima: Fuad Kauma dan Nipan menjelaskan dalam membina, pendidikan perlu memperhatikan pada pendidikan aqidah, ibadah, akhlak serta ekonomi. Adapun persamaannya bahwa peran ibu dalam membina anak perlu ditempuh dengan pendidikan-pendidikan Islam.

Dengan ini, penulis dapat menganalisis bahwa peran ibu sebagai Pembina yang akan membentuk kepribadian anak yang mana anak perlu asupan dari Pembina berupa pendidikanpendidikan yang islami seperti pendidikan aqidah, pendidikan akhlak, pendidikan intelektual, pendidikan jasmani dan pendidikan ekonomi.

\section{B. Peran Ibu Sebagai Pendidik bagi Anak dalam Keluarga}

Menurut Djumransjah dkk., dalam bukunya Pendidikan Islam Menggali Tradisi Mengukubkan Eksistensi mengatakan peran seorang ibu sesuai dengan fungsi dan tanggung jawabnya dalam pendidikan anak adalah: 1) Sumber dan pemberi kasih sayang, 2) Mengasuh dan memelihara, 3) Tempat mencurahkan isi hati, 4) Mengatur kehidupan dalam rumah tangga, 5) Pembimbing hubungan pribadi, dan 6) Pendidik dalam segi-segi emosional. ${ }^{41}$

Sebagaimana yang telah dijelaskan sebelumnya, bahwa peran ibu sesuai dengan konsep-konsep di atas yaitu: ibu sebagai pendidik adalah: ibu yang mampu mendidik anaknya dengan nilai keIslaman sejak masih dini, memiliki budi pekerti yang baik (akhlakul karimah), selalu menjaga

\footnotetext{
${ }^{40}$ Fuad Kauma dan Nipan, Membimbing Istri Mendampingi Suami, (Yogyakarta: Mitra Pustaka, 1997), h.197-202.

${ }^{41}$ Djumransjah dkk., Pendidik Islam Menggali Tradisi Mengukubkan Eksistensi..., h.86.
} 
perilakunya agar menjadi teladan bagi anaknya, memiliki sikap penyabar, sopan serta lembut dalam berbicara agar kelak sang anak dapat memiliki kepribadian yang tangguh dan baik.

Ibu sebagai teladan bagi anak yakni teladan seorang ibu untuk membentuk kepribadian anak, agar anak-anaknya tumbuh menjadi pribadi yang baik, sudah seharusnya ibu memiliki sikap seperti Rasulullah SAW yang patut dicontoh oleh anak seperti mendidik dengan keteladanan, menasehati melalui perkataan, kasih sayang yang begitu dan tak lupa mendoakan kebaikan untuk anak. Sehingga ini merupakan jaminan awal untuk tumbuh kembang anak dengan baik dan aman.

Seiring dengan itu, ibu sebagai Pembina anak adalah menjadi pembina yang membentuk kepribadian anak, yang mana anak perlu asupan dari pembina berupa pendidikan-pendidikan yang islami seperti pendidikan aqidah, pendidikan akhlak, pendidikan intelektual, pendidikan jasmani dan pendidikan ekonomi.

Dari hal ini sangatlah jelas, bahwa seorang ibu memiliki peran besar dalam semua sektor kehidupan, apabila dalam satu negara seorang ibu menjalankan tugasnya dengan benar dan sesuai dengan hukum agama, maka negara tersebut telah benar-benar menyongsong negara yang berkeadilan yaitu negara yang Baldatun Toyyibatun Wa Robbun Ghofur. Dan apabila dalam suatu negara semua kaum ibunya baik, maka baiklah suatu negara tersebut dan begitu sebaliknya.

\section{KESIMPULAN}

1. Ibu merupakan Madrasah yang paling utama dalam pembentukan kepribadian anak. Di samping itu, ia sangat berperan sebagai figur central yang dicontoh dan diteladani dengan perilaku atau moralitas melalui arahan dalam berbagai keutamaan yang mulia. Untuk mencapai keutamaan ini seperti menanamkan akhlak- akhlak terpuji baik terhadap keluarga maupun di kalangan masyarakat maka para ibu perlu sekali memperhatikan anak-anaknya sejak dini, setiap muncul sifatsifat negatif seperti sombong, congkak, hendaknya mereka segera mengobatinya. Jika sifat ini dipelihara maka di masa yang akan datang perangainya akan cenderung tidak mau menerima nasehat dan tidak mau berkecimpung dengan kelompok-kelompok yang baik. Dalam hal ini sering sekali terjadi bukan hanya pengaruh lingkungan masyarakat saja akan tetapi juga keluarga. Lebihlebih lagi apabila anak-anak hidup dalam sebuah keluarga yang suasana tidak damai dan diliputi oleh nilai-nilai yang tidak teriringi akhlak mulia, maka psycologisnya akan tidak tertanam nilai-nilai moral yang berbasis Islami. Untuk mengatasi problema ini maka seorang ibu merupakan tokoh utama untuk mewujudkan suasana harmonis agar terwujudnya kesuksesan dalam mendidik anak.

2. Dari teori pendidikan Islam sebagaimana yang dipraktekkan Rasulullah, maka tidak diragukan lagi bahwa seorang ibu dalam mendidik anak mempunyai contoh-contoh tersendiri, yaitu seorang ibu harus memiliki suri tauladan yang dapat dicontohkan dalam kehidupannya dan membentuk norma-norma nilai dan akidahnya. Demikian juga bahasa yang digunakan seorang ibu dalam mendidik anak sangat berpengaruh agar anak-anak menjadi orang yang berbudi luhur dan memiliki tutur bahasa yang lembut.

3. Ibu perlu memberikan dorongan belajar bagi anak-anak dengan mendidik mereka menggunakan metode cerita. Karena metode ini ikut serta dalam menanamkan nilai-nilai agama seperti menceritakan kisah-kisah nabi agar melahirkan pengaruh-pengaruh baik pada jiwa anak- 
anak. Selanjutnya pengaruh hiburan dalam mendidik anak juga sangat perlu diperhatikan oleh seorang ibu, agar anak-anak dapat memperoleh kegairahan roda kehidupan dalam belajar sesuai dengan usia anak dan tidak meleset dari nilai-nilai Islam. Semua metode pendidikan ini akan berdampak besar dan jelas dalam menumbuhkembangkan kekuatan-kekuatan potensial yang ada pada anak, lebih-lebih potensi fisik, afektif dan kognitifnya. 


\section{DAFTAR KEPUSTAKAAN}

Abdullah, Adil Fathi, Menjadi Ibu Ideal, Jakarta: Al-Kautsar, 2005

Al Mardhiyah, Abu Al 'Aina, Apakah Anda Ummi Sholihab?, Solo: Pustaka Amanah,1996

Al-Attas, Syed Muhammad Naquib, The Concept of Education In Islam, Malaysia: Art Printing Work, 1991

Al-Hasyimi, Muhammad Ali, Kepribadian Wanita Muslimab Menurut Al-Qur'an dan As-Sunnah, Jakarta: Akademika Pressindo, 1997 , Muslimah Ideal, Yogyakarta: Mitra Pustaka, 2004

Al-Maliki, Muhammad Alawi, Ilmu Ushul Hadis, Yogyakarta: Pustaka Pelajar, 2009

Al-Shabbagh, Mahmud, Tuntunan Keluarga Bahagia Menurut Islam, Bandung: PT Remaja Rosdakarya, 1991

Aly, Hery Noer dan Moenzier, Watak Pendidikan Islam, Jakarta: fisika Agung Lestari, 2000

Arfah, Ummu Syafa Suryani, Menjadi Wanita Shalihah, Jakarta: Eska Media, 2010

Armaiyn, Suryati, Catatan sang Bunda, Jakarta: Al-Mawardi Prima Jakarta, 2011

At-Tirmidzi, Muhammad bin Isa, Sunan At-Tirmdæi, Libanon: Dar Al- Kutub Al-Ilmiyah, 2008

Bali, Wahid Abdus Salam, Kiat Mencetak Anak Shalih, Yogyakarta: Titian Ilahi Press, 2000

Chamidi, Ya'qub, Menjadi Wanita Shalibah dan Mempesona, Jakarta: Mitra Press Studio, 2011

Daradjat, Zakiah, Islam dan Peranan Wanita, Jakart: Bulan Bintang,1978

Daryanto, Kamus Bahasa Indonesia Lengkap, Surabaya: Apollo, 1997

Daulay, Haidar Putra, Sejarah Pertumbuhan dan Pembaruan Pendidikan Islam di Indonesia, Jakarta: Kencana Prenada Media Group, 2007

Departemen Agama RI, Al-Qur'an dan Terjemahan, Jakarta: PT Bumi Restu

Dewey, John, Experience and Education, New York: Touchstone Rockefeller Center, 1997

Dimas, Muhammad Rasyid, 25 Cara mempengarubi Jiwa dan Akal Anak, Jakarta: Pustaka AlKautsar, 2006

Djumransjah, Pendidikan Islam Menggali Tradisi Mengukubkan Eksistensi, Malang : UIN-Malang Press,2007

Habiburrahman, Awaluddin, Terbaik Buat Anakku, Jakarta: Pustaka Group, 2009

Hamid, Muhyiddin Abdul Kegelisahan Rasulullah Mendengar Tangis Anak, Semarang: Dahara Prize, 1994

Hasan, Maimunah, Pendidikan Anak Usia Dini, Yogyakarta: Diva Press, 2010 
Kauma, Fuad dan Nipan, Membimbing Istri Mendampingi Suami, Yogyakarta: Mitra Pustaka, 1997

Martono, Lydia Harlina, dkk, Mengasub dan Membimbing Anak dalam Keluarga, Jakarta: PT Pustaka Antara, 1996

Maunah, Binti, Landasan Pendidikan, Yogyakarta: Teras, 2009

Muhyidin, Muhammad, 9 Bulan Paling Menentukan, Yogyakarta: Diva Press, 2009

Muri'ah, Siti, Nilai-nilai Pendidikan Islam dan Wanita Karir, Semarang: Rasail Media Group, 2011

Nasution, Metode Research Penelitian Ilmiah, Edisi I. Jakarta: Bumi Aksara, 2001

Nizar, Samsul, Filsafat pendidikan Islam, Pendekatan Historis, Teoritis dan Praktis, Jakarta: Ciputat Press, 2002

Prabuningrat, Ray Sitoresmi, Sosok Wanita Muslimah, Yogyakarta: PT Tiara Wacana Yogya, 1997

Rusn, Abidin Ibnu, Pemikiran Al-Ghazali Tentang Pendidikan, Yogyakarta: Pustaka Pelajar, 2009

Santhut, Khabib Ahmad, Menumbubkan Sikeap Sosial Moral dan Spiritual Anak dalam Keluarga Muslim, Yogyakarta: Mitra Pustaka, 1998

Santoso, Ananda, Kamus Lengkap Bahasa Indonesia, Surabaya: Alumni Surabaya

Schaefer, Charles, Bagaimana Mempengarubi Anak, Semarang: Dahara Prize, 1994

Sobur, Alex, Anak. Masa Depan, Bandung: Angkasa, 1986

Sofiudin, Satria Paningit Tumbal Negara, Sumatera Selatan: Ponpes Nurul Ihsan, 2011 Ihsan, 2001 Selamat Tinggal Manusia Kami Kembali ke Langit, Sumatra Selatan: Ponpes Nurul

Tarazi, Norma, Wahai I bu Kenali Anakmu, Yogyakarta: Mitra Pustaka, 2001

Thaha, Khairiyah Hasain, Konsep Ibu Teladan, Surabaya: Risalah Gusti, 1992

Tim Penyusun Kamus Pusat Bahasa, Kamus Besar Bahasa Indonesia, Jakarta: Balai Pustaka, 2007

Undang-undang Guru dan Dosen, Yogyakarta: Pustaka Pelajar, 2009

Yasmadi, Modernisasi Pesantren: Kritik. Nurcholis Madjid Terhadap Pendidikan Islam Tradisional, Jakarta: PT. Ciputat Press, 2005

Yunita, Lidia, Mukjizat Doa Ibu!, Yogjakarta: Diva Press, 2009

Zarman, Wendi, Ternyata Mendidik Anak cara Rasulullah Itu Mudab dan Efektif, Bandung: Ruang Kata, 2012 